\title{
肺癌術後癌遺残, 再発例に対するパクリタキセルの著効例
}

\author{
小田 誠 1 谷内 毅 $1 \cdot$ 田村昌也 $1 \cdot$ 渡邊 剛 1
}

要旨一一目的. 最近 4 年間に, 非小細胞肺癌術後再発 20 例および術後癌遺残 2 例の計 22 例に対してパクリタキセル を用いた化学療法を施行した。このうち Complete Response (CR) が得られた 2 例を呈示する. 症例 1. 69 歳, 男性.

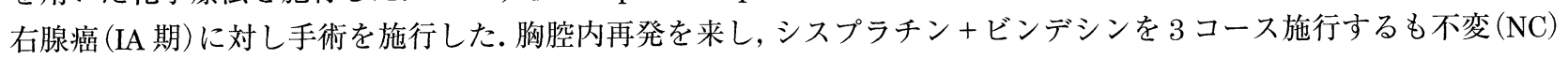
であった. 再手術にて, 多発癌と診断された. その後左肺に多発転移巣を認めたため, カルボプラチントパクリタキセ ルを 4 コース施行し, 転移巣はほほ消失した. パクリタキセル隔週投与を計 7 コース施行し, 現在再発の徴候は認めて いない. 症例 2. 50 歳, 女性. 胸膜播種を伴う右 $\mathrm{S} 10$ の腫瘍に対して, 手術 (非完全切除) を施行した. 中分化型腺癌 (pT4N0M1, IV 期) と診断された. カルボプラチン +パクリタキセルを 3 コース施行したが術後遺残した肺転移巣は NC であったため, パクリタキセル隔週投与を開始した. 20 カ月後 CR が得られ, 計 25 コース終了時点で一旦化学療法を 中止した. 現在無再発生存中である. 結論. 非小細胞肺癌に対するパクリタキセルを用いた化学療法は, 術後再発例や 癌遺残例に対しても治療の一選択肢となり得ると考えられた。（肺癌. 2003;43:961-966）

索引用語——ハクリタキセル, 非小細胞肺癌, 化学療法

\section{Chemotherapy of Two Cases of Recurrent or Residual Non-small Cell Lung Cancer Responding Completely to Paclitaxel}

\author{
Makoto Oda ${ }^{1}$; Takeshi Yauchi ${ }^{1}$;Masaya Tamura ${ }^{1}$; Go Watanabe ${ }^{1}$
}

\begin{abstract}
Purpose. In the has 4 years, we performed chemotherapy using paclitaxel (TXL) for 20 cases of recurrent non-small cell lung cancer and two cases of residual lung cancer patients. In this report, we present two cases showing complete remission. Case 1. The patient was a 69 -year-old man who underwent an operation for stage IA adenocarcinoma. Thirty-eight months after the operation, this patient showed intrathoracic recurrence. No response was available after three couses of treatment using CDDP + VDS. This case was diagnosed as metachronous double primary lung cancer after the re-operation. Multiple recurrent tumors appeared in his left lung. Complete response was obtained after four courses of CBDCA + TXL. The patient is alive with no recurrence after seven courses of weekly TXL. Case 2 . A 50-year old women underwent a non-curative operation for the tumor in the right S10 with intrathoracic dissemination. The pathological diagnosis was pT4N0M1, stage IV. The weekly TXL therapy was started because the residual tumors revelaed no response to the three courses of CBDCA + TXL. Complete response was obtained 20 months after the weekly TXL, therapy was started. The patient is alive with no sign of recurrence after 25 courses of weekly TXL therapy. Conclusion. Chemotherapy using TXL may be a promising regimen for the treatment of recurrent or residual non-small cell lung cancer. (JJLC. 2003;43:961-966)
\end{abstract}

KEY WORDS - Paclitaxel, Non-small cell lung cancer, Chemotherapy

1 金沢大学心肺 $\cdot$ 総合外科.

別刷請求先：小田 誠，金沢大学心肺・総合外科, $\bar{\top} 920-8641$ 石川県金沢市宝町 13-1 (e-mail: odamak@med.kanazawa-u.ac.jp).

${ }^{1}$ Department of General and Cardiothoracic Surgery, Kanazawa University Graduate School of Medicine, Japan.
Reprints: Makoto Oda, Department of General and Cardiothoracic Surgery, Kanazawa University Graduate School of Medicine, 13-1 Takara-machi, Kanazawa, Ishikawa 920-8641, Japan(e-mail: odamak@med.kanazawa-u.ac.jp).

(C) 2003 The Japan Lung Cancer Society 
はじめに

新規抗癌剤であるパクリタキセルは，今まで非小細胞 肺癌に用いられてきた抗癌剤とは作用機序が異なり，進 行非小細胞肺癌に対する治療效果が期待されている. 今 回我々は術後再発をきたした肺癌症例と術後に癌が遺残 した肺癌症例にたいしてパクリタキセルを用い, Complete Response（CR）を得られたので報告する。

\section{対 象}

1999 年から 2003 年までに教室で非小細胞肺癌術後再 発 20 例および術後癌遺残 2 例の計 22 例に対してパクリ タキセルを用いた化学療法を施行した。このうち CR を 術後再発 1 例と術後癌遺残 1 例の 2 例に得られた。これ らの症例を呈示する.

症例 1

症例 : 69 歳, 男性.

喫煙歴：40 本 $/$ 日 $\times 47$ 年間.
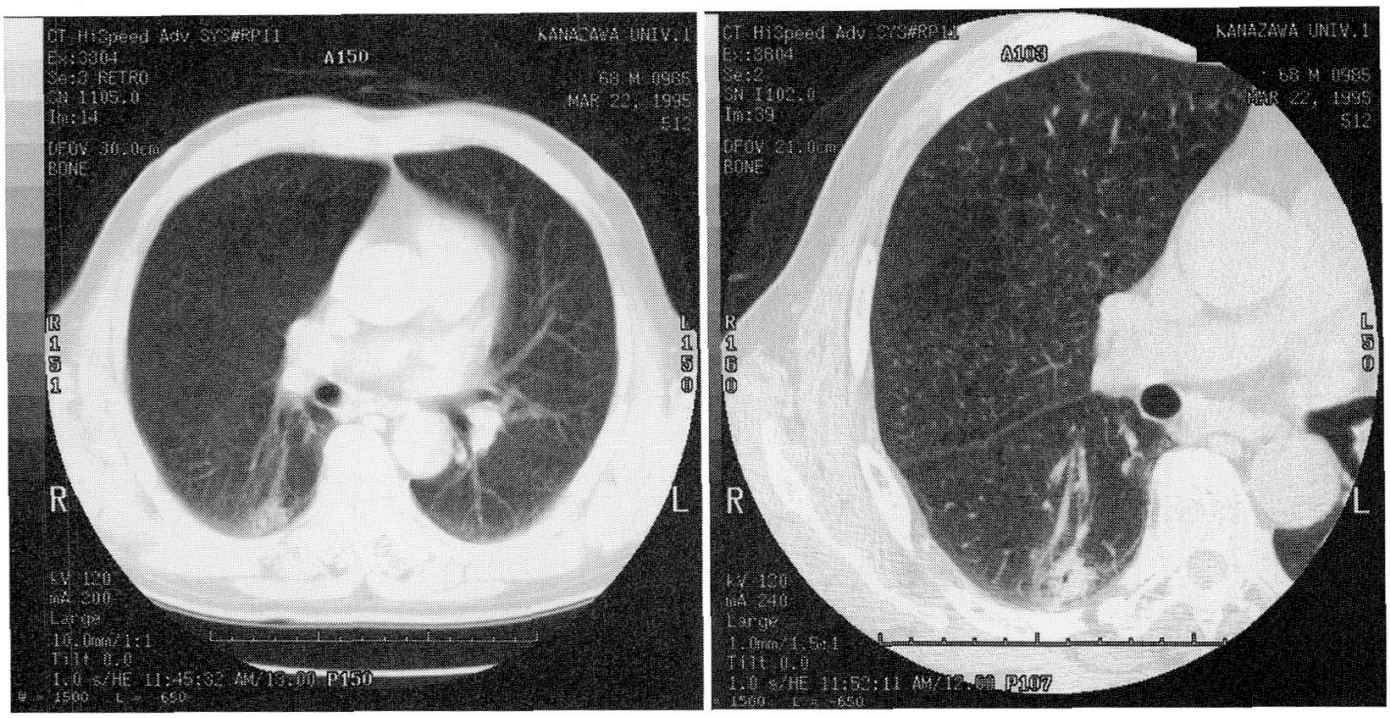

Figure 1. Preoperative chest CT of Case 1. Chest CT shows a well-defined and solid mass measuring 15 mm (Left). High resolution CT reveals a tumor with slightly lobulated margin (Right).
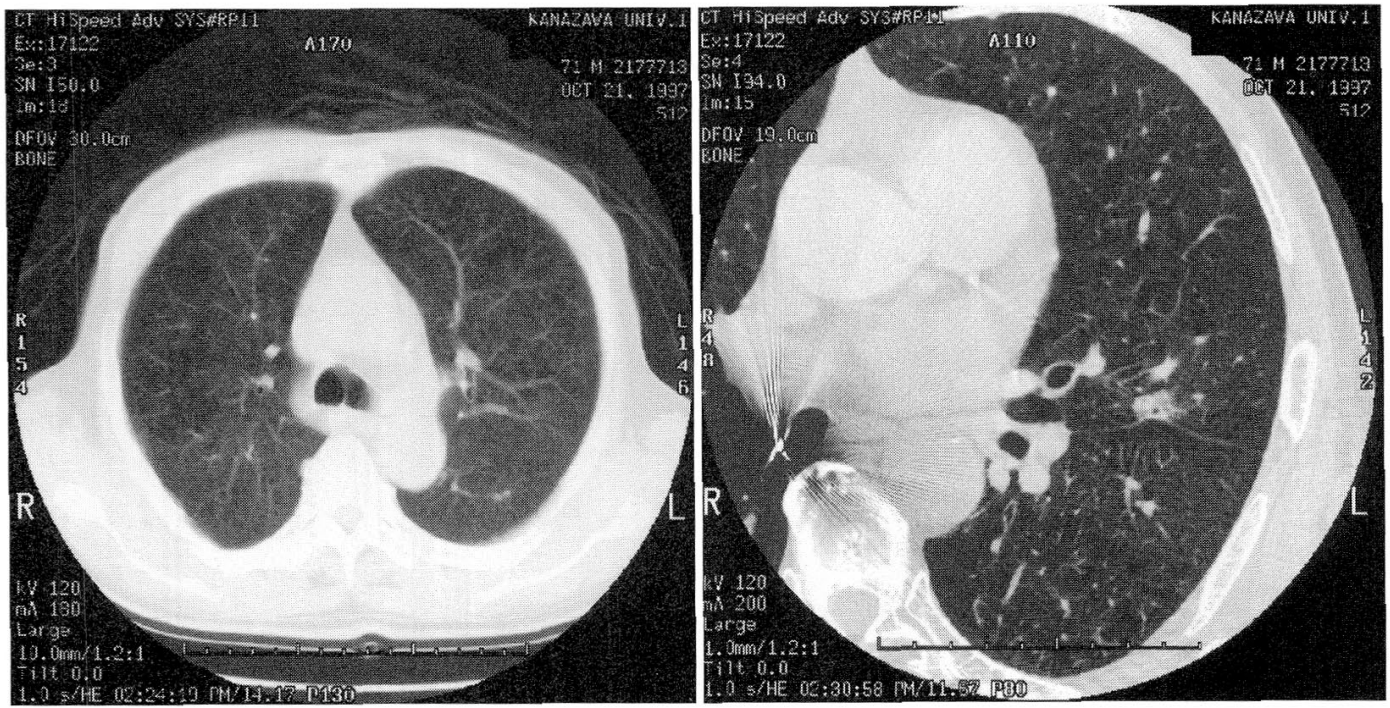

Figure 2. Chest CT findings after chemotherapy using CDDP and VDS. The tumor size revealed no change. The tumor in the left $\mathrm{S}^{6}$ (Left). The tumor in the left $\mathrm{S}^{4}$ (Right). 

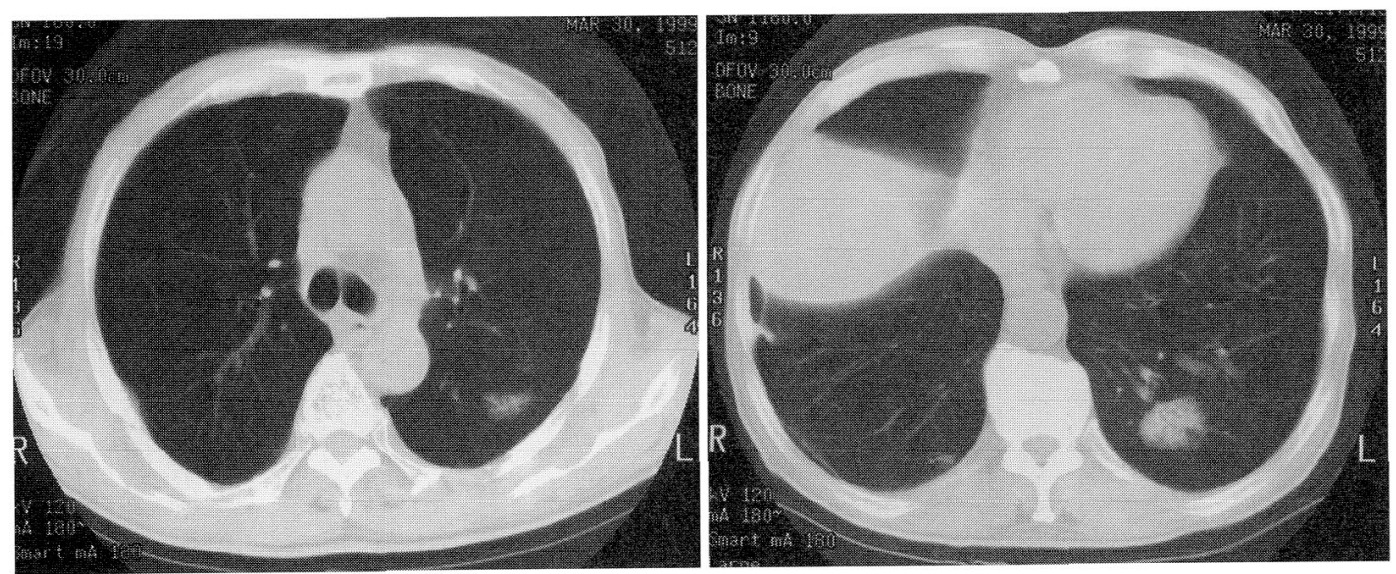

Figure 3. Chest CT findings 5-year after the operation. The tumor in the left $\mathrm{S}^{6}$ (Left). The tumor in the left $\mathrm{S}^{10}$ (Right).
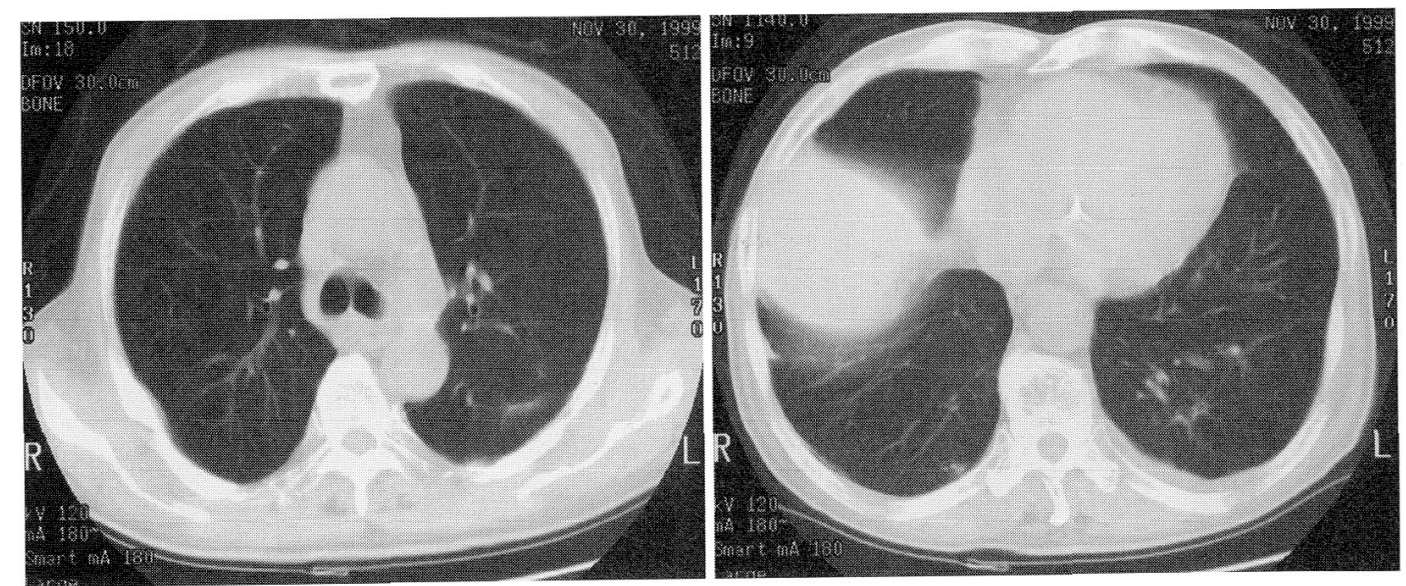

Figure 4. The tumor in the $\mathrm{S}^{6}$ (Left) and $\mathrm{S}^{10}$ (Right) had completely disappeared after chemotherapy using TXL and CBDCA.

臨床経過：検診での胸部レントゲン写真にて右中肺野 の結節影を指摘され当科を受診した．胸部 CT では右 $\mathrm{S}^{6}$ に辺縁不明瞭で内部に細気管支の透亮像を有する約 1.5 $\mathrm{cm}$ 大の腫瘤影を認めた(Figure 1). 1994 年 3 月 29 日胸 腔鏡補助下右肺下葉切除術（ND2a）を施行した. 病理診 断は中分化型乳頭腺癌で病期は pT1N0M0, IA 期であっ た. 術後はテガフール・ウラシル $250 \mathrm{mg} /$ 日 $\times 2$ 年間の 内服を行った。

1997 年 5 月 (71 歳時) 胸部 $\mathrm{CT}$ にて左 $\mathrm{S}^{4}$ と $\mathrm{S}^{6}$ に結節 影が出現し, 再発と考兄られた. 1997 年 5 月 30 日よりシ スプラチン $120 \mathrm{mg}$ (day 1) +ビンデシン $4.5 \mathrm{mg}$ (day $1 ， 8 ）$ を 3 コース $(5,7,8$ 月）施行するも CT 上不変で あった (Figure 2). 同時多発肺癌も疑われたため, 1997 年 11 月 21 日左肺下葉部分切除㧍よび舌区切除術を施行 した。病理䛦断では 2 力所の腫瘍は初回手術と組織像は
同じであるが同時多発肺癌の可能性が高いとの結果を得 た。

その後外来にて経過観察していたが，1999 年 3 月, CT にて左肺に 4 力所の多発転移巣を認めた (Figure 3). 1999 年 4 月 28 日からカルボプラチン $400 \mathrm{mg}$ （2 時間点 滴静注)，パクリタキセル $210 \mathrm{mg}$ (静注)を 1 投 3 休で計 4 コース施行した。化学療法開始時点での performance status（PS）は0であった。1999 年 11 月のCT（Figure 4)では 4 力所の転移巣はほぼ消失した。 2000 年 2 月から パクリタキセル毎週投与 $90 \mathrm{mg}$ (1 時間点滴静注) 6 投 2 休を計 7 コース施行. 2001 年 7 月からは外来で無治療経 過観察をしているが再発の徵候は認めていない。また， 経過中 grade 3 以上の有害事象は認めていない.

症例 2

症例 : 50 歳, 女性. 

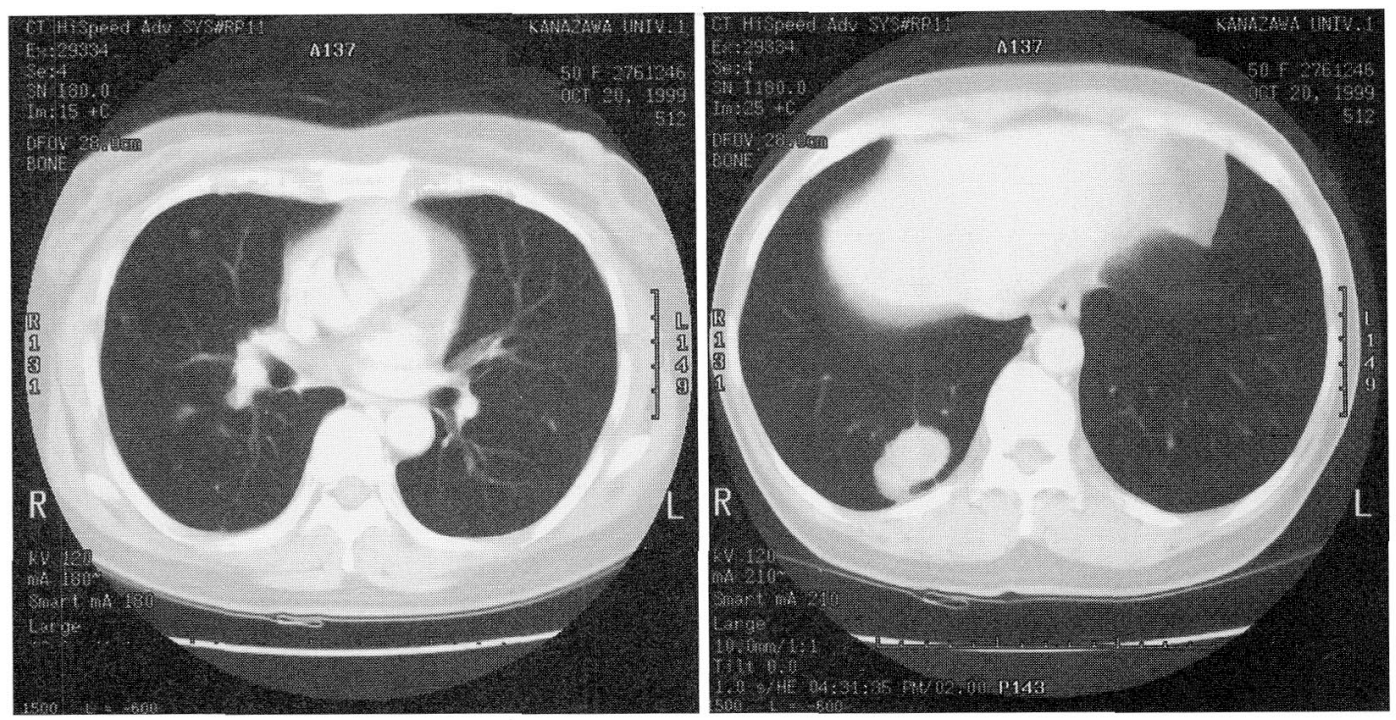

Figure 5. Preoperative chest CT of Case 2. Small nodules were scattered in the right middle and lower lobe. Pleural dissemination were suspicius (Left). CT shows well-defined and solid mass measuring $4.0 \times$ $3.5 \mathrm{~cm}$ with speculation and pleural indentation (Right).
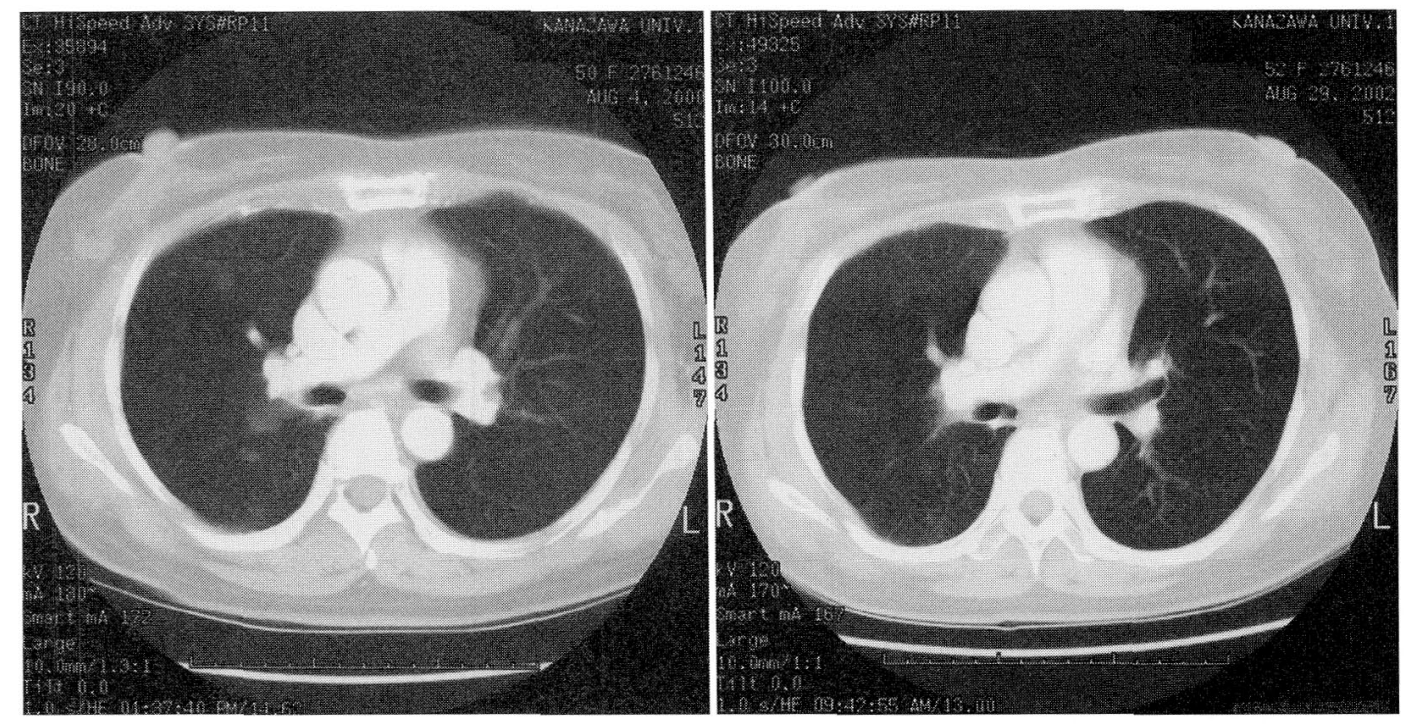

Figure 6. The tumor in the middle and lower lobe (Left) and $\mathrm{S}^{10}$ (Right) had completely disappeared after chemotherapy using TXL and CBDCA.

喫煙歴：なし.

臨床経過：検診にて胸部異常陰影を指摘され，1999 年 10 月 25 日精查加療目的に当科紹介入院となった.

入院時血.液生化学検査では CEA が $117.7 \mathrm{ng} / \mathrm{ml}$ と高 值を認めた。胸部レントゲン写真では右下肺野に $\phi 3.5$ $\mathrm{cm}$ 大の辺縁不整・境界明瞭な mass を認めた. 胸部 CT (Figure 5) では，右中下葉に小結節院影が多発してみら れ，葉間裂に沿った多発小結節陰影も認め，胸膜播種と
考えられた。また右 $\mathrm{S}^{10}$ に径 $4.0 \times 3.5 \mathrm{~cm}$ 大の，胸膜陥入 像を伴う mass を認めた。明らかな縦隔リンパ節の腫脤 は認めなかった。その他, 画像所見で遠隔転移は認めな かった。

1999 年 11 月 1 日右肺下葉 $\left(\mathrm{S}^{10}\right)$ 部分切除 + 胸膜切除 術施行. 病理診断は中分化型乳頭状腺癌で臨床病期 IV 期 (pT4N0M1) であった。この時点でのPSは0であった. 1999 年 12 月 10 日よりカルボプラチン, パクリタキセル 


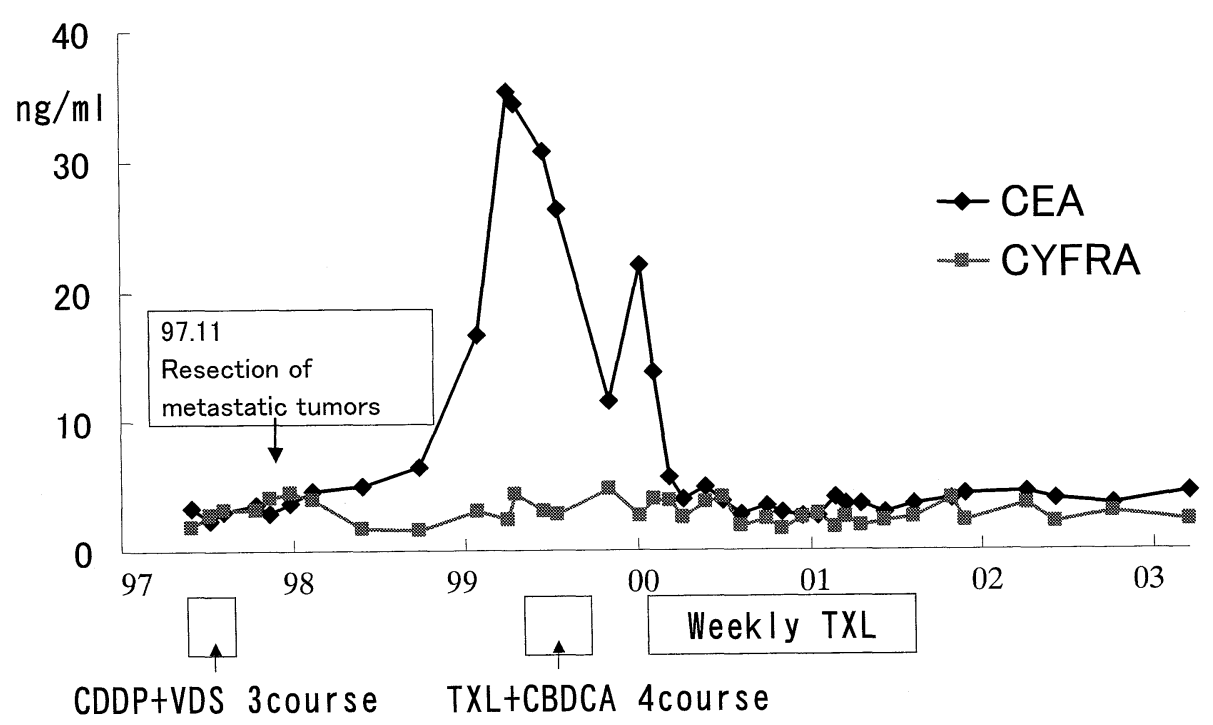

Figure 7. Clinical and treatment course of Case 1.

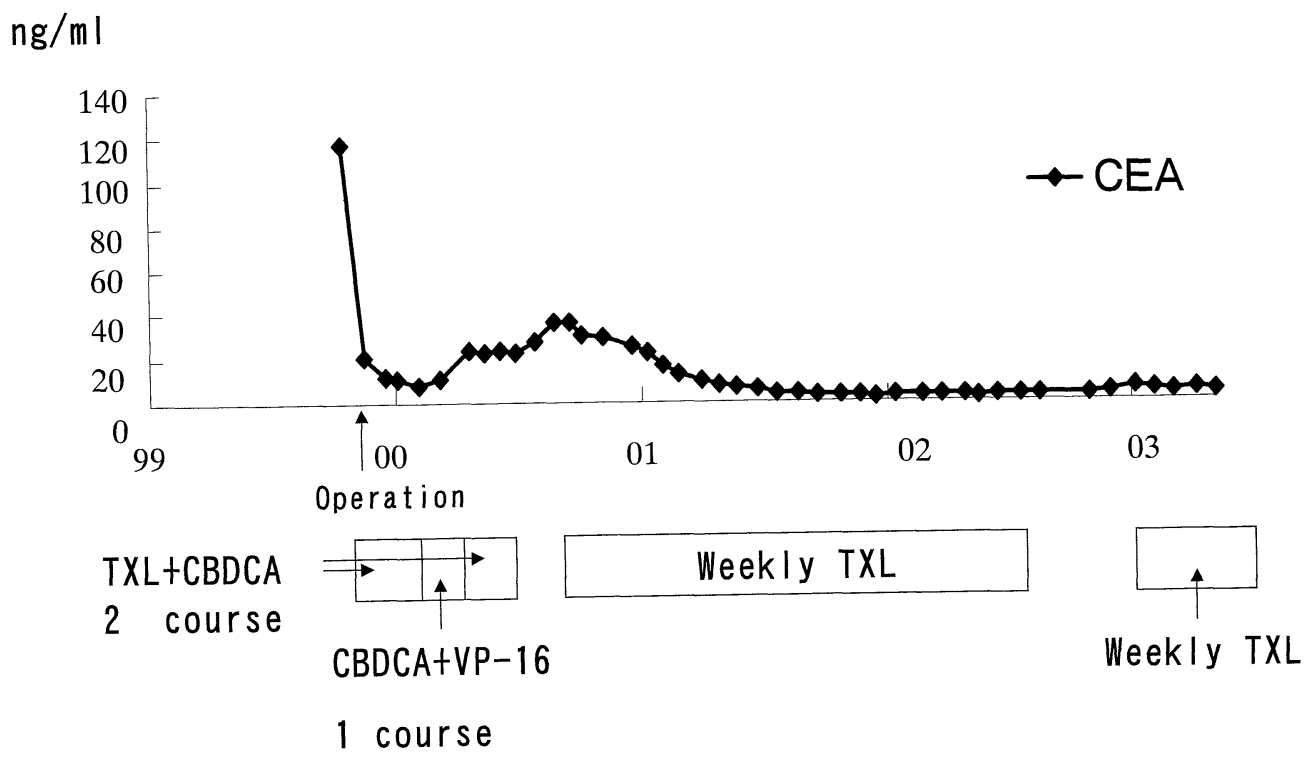

Figure 8. Clinical and treatment course of Case 2.

を 2 コース施行. その後 2000 年 2 月 14 日よりカルボプ ラチン，エトポシドを 1 コース施行し,さらに5月 1 日 にカルボプラチン $(600 \mathrm{mg})$ ，パクリタキセル $(220 \mathrm{mg})$ を 1 コース施行した. しかし, 術後一旦低下した CEA が徐々に上昇し，また， CT 上 NCであったため， 2000 年 9 月 8 日からパクリタキセル毎週投与 $(120 \mathrm{mg}) 3$ 投 1 休を開始した. その後, CEA の低下, CT 上腫瘍の縮小が みられたので治療継続し 2001 年 9 月からは 2 投 1 休と した. 2002 年 8 月の CT (Figure 6) では残存腫瘍は確認 できず CR と診断し計 25 コース終了時点で一旦化学療
法を中止した。 その後 2003 年に入り CEA のごく軽度の 上昇を認めたためパクリタキセル毎週投与 2 投 1 休を再 開したが, 現在無再発生存中である. また, 経過中 grade 3 以上の有害事象は認めていない.

\section{考 察}

パクリタキセルは Texus brevifolia (イチイ科, 米国西 部産）の樹皮から抽出されたタキサン環を有するジテル ビン誘導体であり, 細胞分裂を阻害して抗腫瘍活性を示 す. 1 今回, 我々は術後再発および癌遺残非小細胞肺癌に 
対し,パクリタキセルを用いた化学療法により Complete Response（CR）が得られた 2 例を経験した.

進行非小細胞肺癌に対する化学療法はシスプラチンを 含む多剤併用療法が主流を占めてきた。また，1990 年代 に開発が進められたパクリタキセル,ビノレルビン, ジェ ムザール，ドキタキセルなどの新規抗癌剤を用いた化学 療法がシスプラチンを含む first-line chemotherapy が無 効であった症例にも著効したという報告 2,3 や, 転移・再 発症例に対しても有効であったとする報告 3,4 があるな ど，期待が大きい新規抗癌剤である。しかし，その投与 スケジュールや投与量，併用療法，使用期間については 現在検討が重ねられている．現在までのところ，その投 与方法としてはカルボプラチン+パクリタキセルと dose-density を高めたパクリタキセル毎週投与，低用量 パクリタキセル毎週投与などがあり，それらに放射線療 法を組み合わせて行われている.5,6 European Organization for Research and Treatment of Cancer による第 II 相 試験 (EORTIC08958)によると, Stage IIIA 期非切除非小 細胞肺癌に対してカルボプラチン+パクリタキセルのレ ジメンで奏効率 $64 \%, 1$ 年生存率 $68.5 \%$ が得られたと報 告されている.7 またパクリタキセルは他の薬剤に比べ, 細胞毒性が低く, 副作用も比較的少ないため, ステージ I, II 期といった症例に対しても術前化学療法として施行 しうる可能性もあると報告されている.8

今回の我々の投与法は, 症例 1 ではカルボプラチン + パクリタキセルが著効し, その後パクリタキセル毎週投 与へと変更し, $\mathrm{CR}$ を維持している. また症例 2 では, カ ルボプラチン+パクリタキセルでは NCであったが, そ の後パクリタキセル毎週投与へと変更し著効を認めた. 22 例中, 2 例に CR が得られたことは, 注目に值すると思 われる，著効した症例は 2 例共に，病変が胸腔内に限局 していた. 症例 1 についてはパクリ夕キセル毎週投与で 総量にして $3780 \mathrm{mg}$, 症例 2 については $9000 \mathrm{mg}$ を投与 し，再発を認めなかったため，投与を一旦中止した。 パ クリタキセル毎週投与の継続期間については，未だ一定 の見解は得られていない. 自験例においても, 慎重な経 過観察が必要である.

乳癌や卵巣癌の領域ではコスト面および骨䯣抑制など 副作用の面から，パクリタキセル毎週投与が有用と報告 されている.9 特に症例 2 においては, パクリタキセルは カルボプラチンとの併用では効果を示さなかったもの の, 毎週投与とすることで, dose intensity を高め, 著効 を示した. 本例に関しては, 腫瘍マーカーや画像診断に よる効果判定により, 適宜使用薬剤を変更したことで症
例にあった薬剤・投与方法を見つけることができ，予後 改善につながったと考えられる。

今後は抗癌剂感受性試験や遺伝子解析を抗癌剤選択の 補助として, より効果の高い化学療法が施行可能となる ことが期待される.

\section{まとめ}

非小細胞肺癌に対するパクリタキセルを用いた化学療 法は生存期間の改善が期待でき，耐容性のある治療法で あり, 術後再発例や癌遺残例に対しても有効な治療とな り得ると考えられた.また, 経過中の画像診断や腫瘍マー カー, 自覚症状などを適宜評価し, 効果のないものに関 しては積極的にレジメを変更することにより個々の症例 に適した薬剤を見つけていくことも必要であると考えら れた。

\section{REFERENCES}

1. 古瀬清行, 有吉 寛, 藤原久義, 他. 非小細胞肺癌に対す る Pacritaxel の後期第 II 相試験. 新薬と臨床. 1997;5 (46): 487-497.

2. Juan O, Albert A, Villarroya $\mathrm{T}$, et al. Weekly paclitaxel for advanced non-small cell lung cancer patients not suitable for platinum-based therapy. Neoplasma. 2003;50:204-209.

3. 加藤和宏, 河崎雄司, 矢野修一, 他. Paclitaxel $の$ Weekly 投与にて著明な腫瘍の縮小を認めた進行非小細胞肺癌の 1 例. 癌と化学療法. 2001;28:1277-1281.

4. Alberola V, Cortesi E, Juan O. Weekly paclitaxel in the treatment of metastatic and/or recurrent non-small cell lung cancer. Crit Rev Oncol Hematol. 2002;44 (Suppl): S31-S41. Review.

5. Belani CP, Barstis J, Perry MC, et al. Multicenter, randomized trial for stage IIIB or IV non-small-cell lung cancer using weekly paclitaxel and carboplatin followed by maintenance weekly paclitaxel or observation. J Clin Oncol. 2003;21:2933-2939.

6. Juan O, Albert A, Ordono F, et al. Low-dose weekly paclitaxel as second-line treatment for advanced non-small cell lung cancer: a phase II study. Jpn J Clin Oncol . 2002; 32:449-454.

7. Obrien MER, Splinter T, Smit EF, et al. Carboplatin and paclitaxol (Taxol) as an induction regimen for patients with biopsy-proven stage III AN2 non-small cell lung cancer: an EORTC phase II study (EORTC08958). Eur $J$ Cancer. 2003;39:1416-1422.

8. Greco FA. Paclitaxel-based combination chemotherapy in advanced non-small cell lung cancer. Lung Cancer. 2001;34:S53-S56.

9. Hainsworth JD, Bueeis HA, Litchy S, et al. Weekly docetaxel in the treatment of elderly patients with advanced non-small cell lung carcinoma. Cancer. 2000;89:328-333. 